\title{
COMMUNITY-BASED NATIONWIDE CAPACITY BUILDING FOR GIS-BASED INTEGRATED FLOOD MANAGEMENT
}

\author{
Y. Kwak ${ }^{1}$, K. Muraoka ${ }^{2}$ *, K. Asai ${ }^{2}$ \\ ${ }^{1}$ International Centre for Water Hazard and Risk Management (ICHARM-UNESCO), Public Works Research Institute (PWRI) 1-6 \\ Minamihara, Tsukuba, 305-8516 Japan - kwak55@pwri.go.jp \\ ${ }^{2}$ Graduate School of Sciences and Technology for Innovation, Yamaguchi University, 2-16-1 Tokiwadai, Ube, 755-8611 Japan - \\ t008wc@yamaguchi-u.ac.jp *, kido@yamaguchi-u.ac.jp
}

Commission VI, WG VI/4

KEY WORDS: Bangladesh, integrated flood management (IFM), flood action, risk information

\begin{abstract}
:
After the development of a flood action plan (FAP) in 1988, the Bangladesh government has led practical actions for nationwide flood management. However, Bangladesh is on its way to improve the capacity and knowledge of sustainable infrastructure and nonstructural countermeasures. Local government and communities are also struggling to mitigate flood risk and severe damage. Therefore, a government-driven strategy of capacity building on sustainable flood risk management is an inevitable process to support local authorities' responsibility under the leadership. This pilot study introduced the GIS-based integrated flood management (GiFM) for improving nationwide flood risk management at different levels from communities. First, we proposed the conceptual framework of GiFM to strengthen local government-based capacity focusing on a cost-effective way under the FAP. Then the proposed GiFM employed hydro-GIS geo-database and Earth Observation (EO) data for sharing information on the current flood risk situation including flood monitoring, forecasting and river embankment erosion in transboundary river basins. For flood risk reduction, the prototype of GiFM showed a good example of consultation and action plan to realize high-priority demands at all levels of multi-stakeholders, from decision makers to residents who are living in vulnerable low-lying floodplains of Bangladesh.
\end{abstract}

\section{INTRODUCTION}

Bangladesh is located in one of the largest deltas in the world with three mighty rivers of the Ganges, the Brahmaputra and the Meghna (GBM). These rivers carry 112 billion $\mathrm{m}^{3}$ of surface water flow in the wet season (July to September), 3.7 billion $\mathrm{m}^{3}$ in the dry season (January to March), and 1,100 million tons of sediment annually. In addition to this geographical condition, hydrological and meteorological issues such as flash floods and cyclones are responsible for the damage of embankment. As a result, $22 \%$ of the country's area is affected by floods annually and $60 \%$ experiences a massive flood in almost every 10 years. Overall 11,436 km of embankments in the country (Bangladesh Water Development Board, 2016) are in vulnerable conditions, which is deeply associated with the livelihoods of the people and the economic growth. Flooding due to embankment failures causes huge damage to the livelihoods and the economic growth every year.

Bangladesh ranked as 5th most disaster-prone country in the world (World Risk Report, 2014). Currently Bangladesh is shifting from disaster response to disaster risk reduction, but still does not have adequate capacity and knowledge to build sustainable infrastructures. Therefore, it is necessary to consider sustainable methods considering the Build Back Better priority under the Sendai Framework. The Government of Bangladesh is now finalizing the Seventh Five Year Plan for Fiscal Year (FY)2016-2020. Disaster risk reduction (DRR) and climate change adaptation (CCA) are mentioned among the priority issues to reduce people's exposure risk and vulnerability against hazards. According to the draft Seventh Five Year Plan for FY2016-2020 and Sustainable Development Goals (SDG) 2030 (United Nations, 2015), the Bangladesh government focused on sustainable infrastructures to stabilize the current economic growth.

Bangladesh tries to deal with floods and disasters with structural and non-structural measures. Systematic structural measures began by implementing flood control projects in the 1960s after the colossal flood of 1963. Non-structural measures have introduced in the 1970s. Flooding is a natural phenomenon, which cannot be prevented. Complete flood control is not in the interest of most Bangladeshi farmers. Flood control measures and policies should be directed to mitigate flood damage, rather than flood prevention. Resources should be allocated to help people adopt a life style that is conformable to their natural environment. Indigenous solutions such as changing housing structures and crop patterns can help reduce flood damage. Moreover, good governance and appropriate environmental laws, acts and ordinances will be necessary to achieve sustainable economic development and reduce environmental degradation. In addition, the implementation of an improved real-time flood and drought warning system can reduce disaster damage, and improved flood forecasting and early warning system, and preparedness measures are helpful to reduce the number of deaths.

The Bangladesh Water Development Board (BWDB) is the main organization of the Bangladesh central government and responsible for water resources development and management. 
BWDB has implemented over 700 large and small projects for water resources management and development in the country, and the operation and maintenance $(\mathrm{O} \& \mathrm{M})$ of constructed structures has been the main duty of BWDB.

The Bangladesh government has been trying to develop a number of methods to reduce flood disasters using both structural and non-structural measures. However, it is still difficult to develop detailed flood hazard maps because there is lack of data and information on river infrastructure, such as DEM and historical inundation maps. Moreover, little has been reported on integrated flood management using a GIS system.

In these circumstances, an inventory survey and the establishment of a GIS-based management system are required to collect information on hydraulic structures and develop effective flood management plans. In this pilot study, we conducted data collection and installed a geo-database system, both of which are mainly targeted at the present conditions of river embankment and water-related structures. This pilot study introduced GIS-based integrated flood management (GiFM) as the prototype of a community-based flood hazard map with satellite-based flood mapping.

\section{METHODOLOGY}

\subsection{Conceptual Framework of GIS-based Flood Management System}

The flow chart of this study is shown in Figure 1. The main objectives of this study are to develop the prototype of an integrated flood hazard map based on identified critical points of embankments along the river, and to introduce the prototype of a flood hazard map for poor data areas such as remote areas in developing countries.

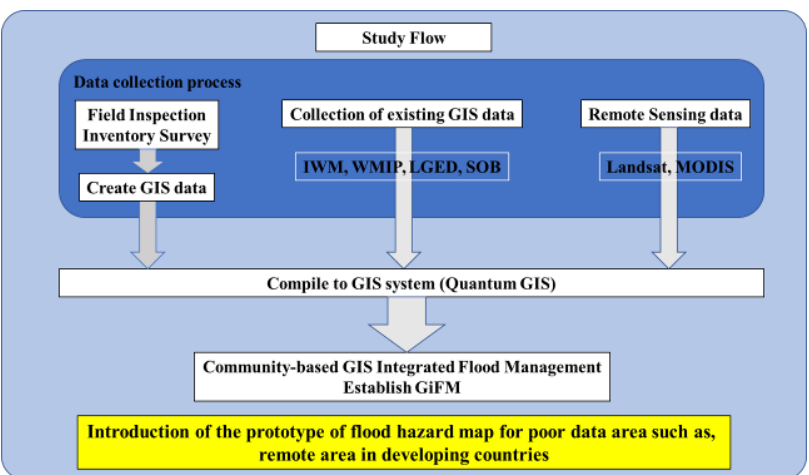

Figure 1. Conceptual framework of a flood management system

\subsection{Pilot Study Area}

Target infrastructure for O\&M of this study is hydraulic structures, in which the external force is flood/stream flow. Therefore, the coastal areas are excluded, for their external force is mainly tidal and wave action. Infrastructure along major rivers are also excluded, because it is usually well maintained by taking advantage of special government attention and donor funds. In this study, flash-flood areas and Haor areas are selected for the case study.

The jurisdictional area of the Moulvibazar O\&M Division Office is the Moulvibazar District of the country located in the north-eastern part of the country and along the left bank of the Kushiyara River, which is the left branch of the Meghna River.
The rivers in the jurisdictional area are international rivers with the upstream basins in India and flow into the Kushiyara River. There are 19 water development schemes and projects completed in the jurisdictional area with the purposes of flood control, drainage improvement, irrigation development, town protection and bank protection, and many of the structures in the area are managed by the office. The locations of the structures managed by the office are grasped by field officials. However, there are no location maps and no ledgers of managed structures shared in the office. In addition, the reports related to the completed projects were scattered and lost.

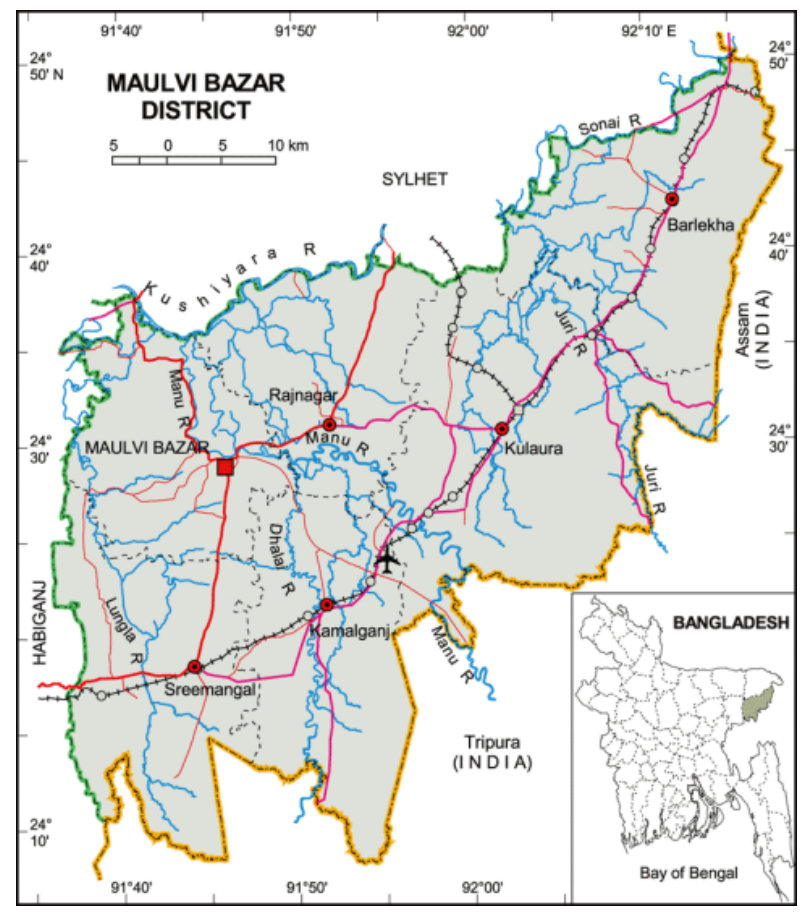

Figure 2. Pilot Study Site in Moulvibazar District

\subsection{GIS Database Used}

(1) Conventional GIS Databases

In Bangladesh, GIS databases have been established by the World Bank-funded Water Management Improvement Project (WMIP) (World Bank, 2008), and those databases were planned to be established for various projects. On the other hand, a GIS database of damage and maintenance records was planned to be established for selected study sites. Damage and maintenance records should be collected as a geo-database and established as a component of the GIS database established by WMIP.

(2) Data collection by Inventory Survey

The basic information on the hydraulic structures under the Moulvibazar division jurisdiction is collected through field investigation. The output is the specifications of the hydraulic structures, and the inventory sheets include sketches and photos. Additionally, line shape data collected from portable GPS track log (Garmin, 2015) are used to update the line data on existing embankments and canals from the Institute of Water Modelling (IWM) and Survey of Bangladesh (SOB). The collected data during 2015 in this activity is more current than the data of IWM and SOB.

(3) Sustainable GIS Application

To maintain and update the geo-database by the officials of the O\&M office, the GIS database has been developed by adapting 
a database system that is manageable for not only system engineers but also civil engineers. The GIS software is Quantum GIS software (version 2.13 used in this study, Copyright (C) 2008 Free Software Foundation, Inc, Boston, MA, USA) that is subject to the GNU General Public License for all end users. Additionally, technical transfer has been conducted according to officials' skill levels on the on-the-job-training (OJT) basis, aiming for officials to acquire solid knowledge.

\subsection{Satellite-based Flood Mapping}

Since the Terra (EOS AM-1) launch in December 1999 by NASA, the Moderate Resolution Imaging Spectroradiometer (MODIS) has been recognized as one of the main contributors to long-term time series as well as near-real-time flood mapping. The daily acquisition of remote sensing data from the MODIS aboard the Aqua enables efficient monitoring of the seasonal change of water bodies, the growing season, and phonological development of vegetation (NASA, 2016). (Source: NASA)

\section{(1) MODIS-derived floodwater index}

The modified land surface water index (MLSWI) was developed and applied to temporal processing to extract floodwater using time-series data. MLSWI is a new index developed by Kwak et al. (2014, 2015), combining bands 2 and 7. The behaviour of the time-series MLSWI value $(0<$ MLSWI $\leqq 1$ ) was evaluated and analysed with in-situ data, training samples and ground truth samples. The equation of MLSWI is as follows:

$$
\operatorname{MLSWI}_{2,7}=\frac{1-\rho_{\mathrm{NIR}}-\rho_{\mathrm{SWIR}}}{1-\rho_{\mathrm{NIR}}+\rho_{\mathrm{SWIR}}}
$$

where $\rho_{\mathrm{NIR}}$ and $\rho_{\mathrm{SWIR}}$ are atmospherically corrected surface reflectance for their respective MODIS bands: band 2 (NIR: 841-876 nm), and bands 7 (SWIR: 2105-2155 nm).

MODIS Aqua data, eight-day composite surface reflectance products selected on the best observations (MYD09A1) were employed in this pilot study. In order to detect the maximum flood extent, we selected 15 images during the monsoon flood season between June and September 2017 from among 46 images.

\section{(3) SfWi: synchronized floodwater index}

For annual flood extent mapping on a transboundary scale and on a global scale, the Synchronized Floodwater Index (SfWi) was developed by taking advantage of the similarity in periodical change behaviour from time-series MLSWI and a hydrograph of water level in the floodplain areas. For better flood monitoring in nationwide flood risk management, SfWi is a new flood detection algorithm of interactive indices with flexibility and scalability based on the conditional functions of the multi-criteria method (Kwak, 2017). After the water level exceeds the flood danger level (Dl) at the stations, SfWi was applied to improve the accuracy of floodwater detection according to the proposed evidence-based hypothesis on the MLSWI.

$$
\operatorname{SfWi}(\mathrm{t})=\left\{\begin{array}{c}
\text { MLSWI }(\mathrm{t}), x \geq \text { Th and if } y \geq \mathrm{DL} \\
0, \text { if, } x<\text { Th and } y<\mathrm{DL}
\end{array}\right.
$$

where $t$ is the composite-day-of-year (DOY) in the year of acquisition, $\mathrm{x}$ is MLSWI values ranging from 0 to $1, \mathrm{y}$ is the river water level at gauge stations, Th is the optimized threshold value of MLSWI, and DL is the flood danger level of river water when a flood occurs.

\section{RESULTS AND DISCUSSION}

\subsection{Inventory Survey of Hydraulic Structures}

The inventory survey of the hydraulic structures in the study area was conducted through field inspection for one year. Table 1 shows the list of collected data in the pilot study period in

\begin{tabular}{|c|c|}
\hline Gathering Data & Information \\
\hline River channel & $\begin{array}{c}\text { Length }(\mathrm{km}) \text {, } \\
\text { GPS coordination }\end{array}$ \\
\hline Drainage channel & $\begin{array}{l}\text { Length }(\mathrm{km}) \text {, } \\
\text { GPS coordination }\end{array}$ \\
\hline Irrigation canal & $\begin{array}{l}\text { Length }(\mathrm{km}) \text {, } \\
\text { GPS coordination }\end{array}$ \\
\hline $\begin{array}{l}\text { Appurtenant Structure } \\
\text { Embankment, Bank and foot } \\
\text { protection work, groin/spur } \\
\text { dike, road, bridge/culvert, }\end{array}$ & $\begin{array}{l}\text { Length (km), Number of } \\
\text { Stations (Nos), } \\
\text { Condition of Structure }\end{array}$ \\
\hline $\begin{array}{l}\text { Water Control Structures } \\
\text { Barrage/large regulator, } \\
\text { sluice/escape, aqueduct, } \\
\text { siphon, pump station }\end{array}$ & $\begin{array}{c}\text { Number of Stations (Nos), } \\
\text { Current Situations, } \\
\text { Condition of Structure }\end{array}$ \\
\hline
\end{tabular}
2015.

Table 1. List of Collected Data

According to the results of the inventory survey, the Manu River is exposed to the progressive erosion of the river bed along the embankment. The embankments on both sides of the river are equally threatened at many places due to the flooding. Figure 4 shows a typical condition of embankment failure. River bank protection works mainly in the form of bank revetment were applied to contain the erosion process and to construct new set-backed embankments to replace eroded portions of the embankments at many places.

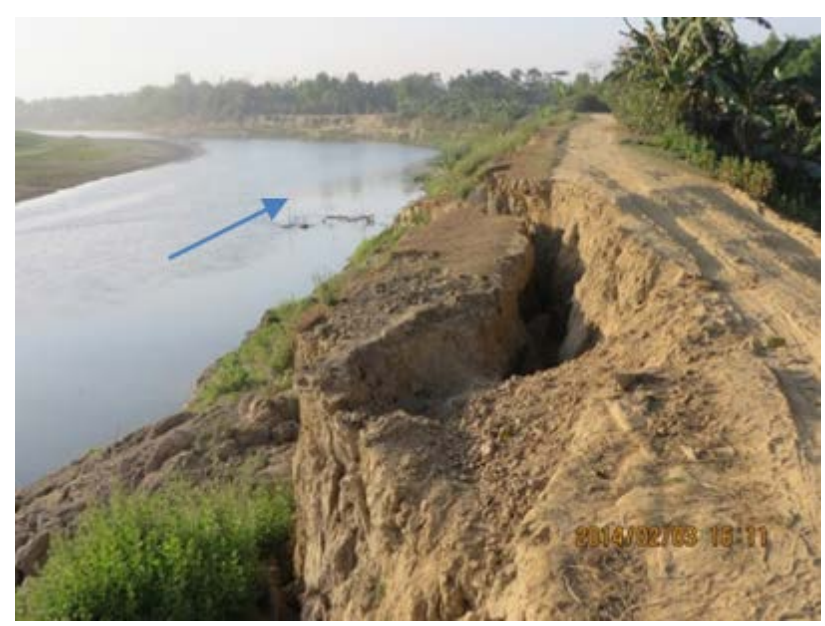

Figure 4. Embankment failure in Manu River. 


\subsection{Development of River Infrastructure Geo-database}

3.2.1 GIS-based river infrastructure management system: The basic information on the hydraulic structures, such as locations, specifications, damage records and maintenance records, is important elements for long-term operation and maintenance of the structures. For the purpose of efficiently accumulating and grasping the specifications of hydraulic structures such as locations and photos, a GIS database has been developed for BWDB O\&M division officials to use and manage as daily work. In consideration of operation by O\&M division officials who do not have expert computer knowledge, the GIS database is simply structured and does not require expert knowledge.

The GIS database mainly consists of "Table of Contents" and "Map View" as shown in Figure 4. The "Table of Contents" is for layer management using an open tree system. The "Map View" is managed using a geographic coordinate system. Additionally, each object of the hydraulic structures and damaged embankments is linked with inventory sheets on the GIS database.

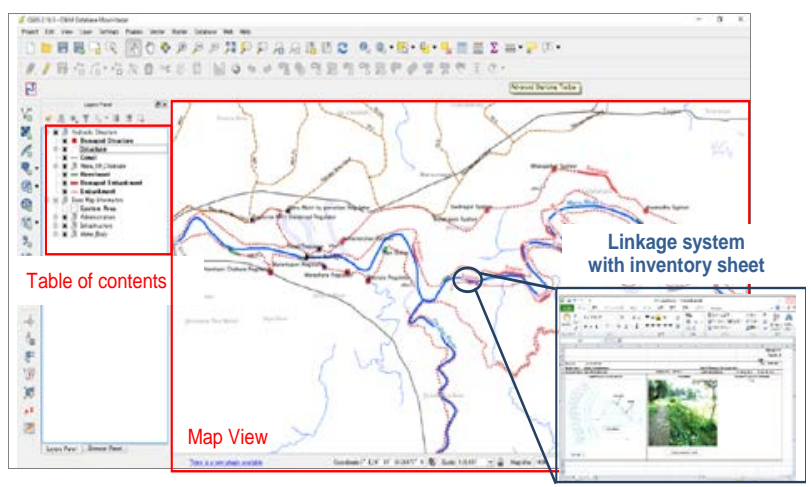

Figure 4. Structure of Operation Folder of GIS Database

3.2.2 Structure of GIS database: The structure of the operation folders and the GIS database layers is shown in Figure 5 and Table 2. Related operation files are stocked in the "O\&M Database Moulvibazar" folder, which should be kept directly under the $\mathrm{C}$ drive. The GIS database consists of 2 types of layer groups. One is the hydraulic structure group for regulators, revetment and embankment; the other is the base map layer group for administrators, infrastructure and natural conditions.

The base map consists of the infrastructure layers (i.e., roads, rail roads, and bridges), the natural condition layers (i.e., rivers, Haors, and elevation), and the administration layers (i.e., boundaries and notations). Although these geo-databases are not directly related to hydraulic structures, it is essential information for identifying hydraulic structures on a map. On the development stage of the aforementioned items, a GIS database has been developed by water management officials in charge of office work.

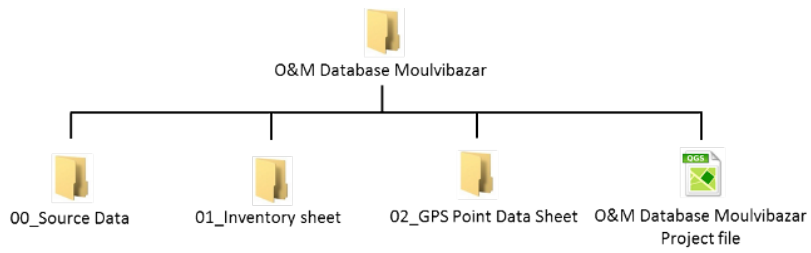

Figure 5. Structure of Operation Folder of GIS Database
3.2.3 Linkage of Inventory Sheet with Geo-database: The results of the inventory survey include the inventory sheets (inventory forms) of respective structures in the form of digital files (MS Excel files). The inventory sheets of respective structures should be confirmed and revised by the technical officials of the office through daily activities of O\&M and shared in the office in order to conduct the O\&M activities efficiently. To facilitate the confirmation and revision of the inventory sheets, the sheets have been linked with the GIS database. Therefore, the users of the GIS database and technical officials of the office can open the digital files of inventory sheets directly by selecting structures in the GIS database. The inventory sheets can be edited and saved by the users, if needed. Sample images of inventory sheets of the structures in the GIS database are shown in Figure 6.

3.2.4 Damage data of hydraulic structures: The inventory survey was conducted not only for the specifications of existing structures but also for the information on damage to the structures. The structural damage information is also included in the GIS database. In the GIS map, the locations of the damaged embankments are displayed as dots or lines in highlighted red colour as shown in Figure 7.

According to the locations of damaged embankments, most of the bank failures concentrated in outer bends along the Manu River. As bank failure is likely to be the critical point of embankment breach, it is important to grasp the relationship between the locations of inundation areas and the locations of the critical points against bank-full flow (discharge) and floods. In order to do so, we employed remote sensing data such as MODIS-derived flood mapping from section 3.3.

\begin{tabular}{|c|c|c|c|c|}
\hline Layer group & Classification & Layer & Source & Reference \\
\hline \multirow[t]{6}{*}{$\begin{array}{l}\text { Hydraulic } \\
\text { Structure }\end{array}$} & \multirow[t]{2}{*}{$\begin{array}{l}\text { Specification of } \\
\text { hydraulic } \\
\text { infrastructure }\end{array}$} & $\begin{array}{l}\text { Embankment, } \\
\text { Channel, Canal (line } \\
\text { data) }\end{array}$ & $\begin{array}{l}\text { IWM, SOB, } \\
\text { Inventory } \\
\text { survey }\end{array}$ & $\begin{array}{l}\text { The Data item is } \\
\text { same as WMIP } \\
\text { database in aspect of } \\
\text { compatibility }\end{array}$ \\
\hline & & $\begin{array}{l}\text { Other hydraulic } \\
\text { structure point data } \\
\text { (ex. Regulator, } \\
\text { Sluice) }\end{array}$ & $\begin{array}{l}\text { IWM, Field } \\
\text { survey } \\
\text { Inventory } \\
\text { survey }\end{array}$ & $\begin{array}{l}\text { The Data item is } \\
\text { same as WMIP } \\
\text { database in aspect of } \\
\text { compatibility }\end{array}$ \\
\hline & \multirow[t]{3}{*}{$\begin{array}{l}\text { Damage records } \\
\text { of hydraulic } \\
\text { infrastructure }\end{array}$} & $\begin{array}{l}\text { Embankment, } \\
\text { Channel, Canal (line } \\
\text { data) }\end{array}$ & $\begin{array}{l}\text { Inventory } \\
\text { survey }\end{array}$ & $\begin{array}{l}\text { Linked with } \\
\text { Inventory sheet }\end{array}$ \\
\hline & & $\begin{array}{l}\text { Other hydraulic } \\
\text { infrastructure point } \\
\text { data (ex. Regulator, } \\
\text { Sluice) }\end{array}$ & $\begin{array}{l}\text { Inventory } \\
\text { survey }\end{array}$ & $\begin{array}{l}\text { Linked with } \\
\text { Inventory sheet }\end{array}$ \\
\hline & & $\begin{array}{l}\text { Other hydraulic } \\
\text { infrastructure point } \\
\text { data (ex. Regulator, } \\
\text { Sluice) }\end{array}$ & $\begin{array}{l}\text { Inventory } \\
\text { survey }\end{array}$ & $\begin{array}{l}\text { Linked with } \\
\text { Inventory sheet }\end{array}$ \\
\hline & Chainage & $\begin{array}{l}\text { Manu river } \\
\text { chainage }\end{array}$ & $\begin{array}{l}\text { developed by } \\
\text { GIS } \\
\text { application }\end{array}$ & $\begin{array}{l}\text { Primary embankment } \\
\text { along both side }\end{array}$ \\
\hline \multirow[t]{8}{*}{ Base Map } & \multirow[t]{2}{*}{ Natural condition } & River & IWM, SOB & $\begin{array}{l}\text { Classified with main } \\
\text { and small river }\end{array}$ \\
\hline & & Lake, Haor & $\begin{array}{l}\text { Existing } \\
\text { Survey report }\end{array}$ & \\
\hline & \multirow[t]{2}{*}{ Infrastructure } & Road & $\begin{array}{l}\text { IWM, SOB, } \\
\text { LGED }\end{array}$ & \\
\hline & & Railway & SOB & \\
\hline & Topographic data & $\begin{array}{l}\text { Digital elevation } \\
\text { map(DEM) }\end{array}$ & USGS & $\begin{array}{l}\text { SRTM 90m resolution } \\
\text { Digital Elevation } \\
\text { Map and Hill shade. }\end{array}$ \\
\hline & \multirow{3}{*}{$\begin{array}{l}\text { Administration } \\
\text { boundary }\end{array}$} & Country boundary & SOB & \\
\hline & & District boundary & SOB & \\
\hline & & Name of place & LGED & Upazila, Union, \\
\hline
\end{tabular}

Table 2. Entire Layer of GIS Database 


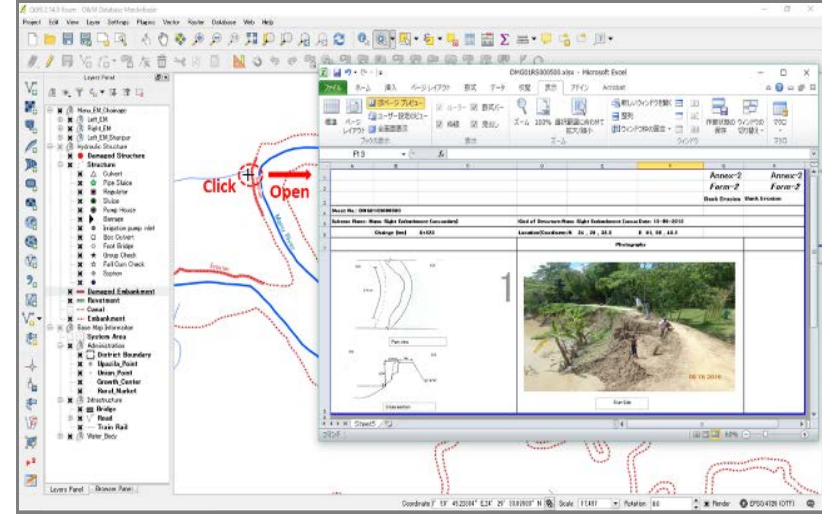

Figure 6. Linkage with GIS Map and Inventory Sheet (Damaged Structure)

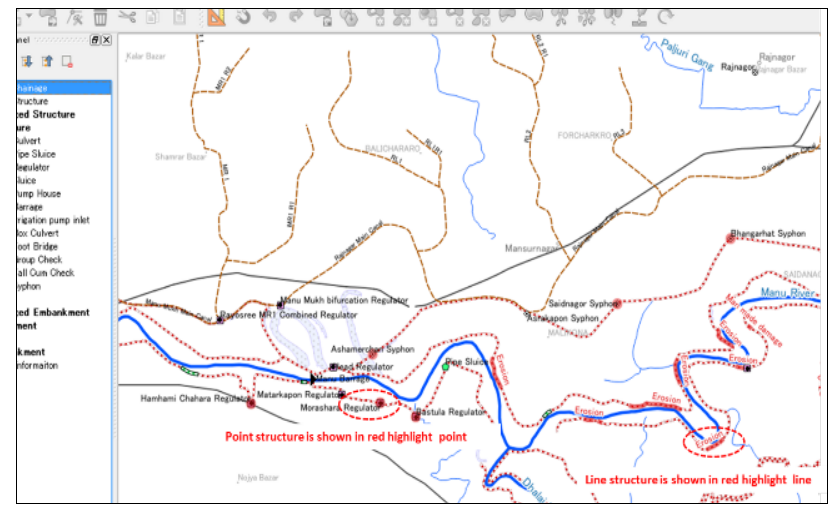

Figure 7. Damaged Structure on GIS Map

\subsection{Floodwater detection from MODIS data}

As a result of prompt flood mapping, pixel-based flood detection was applied to identify the spatial distribution of flood extent. Figures 8 and 9 show the comparative flood maps with damage data of river embankment (red line) in combination with MODIS-detected flood (14-21 Aug. 2017) on the Landsat 8 RGB image (30m spatioa22 Aug. 2017). The black line indicates river embankments from the base layer while the red lines indicate the damaged embankments confirmed in the field inspection. Although there were a turbidity of the water and mixed pixels in the snapshot of images, both resultant maps show a good agreement with the damage data collected in the field inspection. The localized flooding and damaged embankments partially concentrated near the conjunction point of the river network as the critical point. The resultant flood maps illustrate the integrated geo-database as one of the components of the GIS database.

\subsection{GIS-based Integrated Flood Management}

Most developing countries have difficulty in flood hazard mapping because it is hard to improve its accuracy due to lack of data or insufficient information such as flood inundation history, DEM, and the locations and conditions of water related structures. Therefore, the data presented in Figure 9 should be applied to the prototype of a flood hazard map, which can be used for local community-based disaster risk reduction. GiFM can strengthen local government-based capacity in a costeffective way under the FAP.

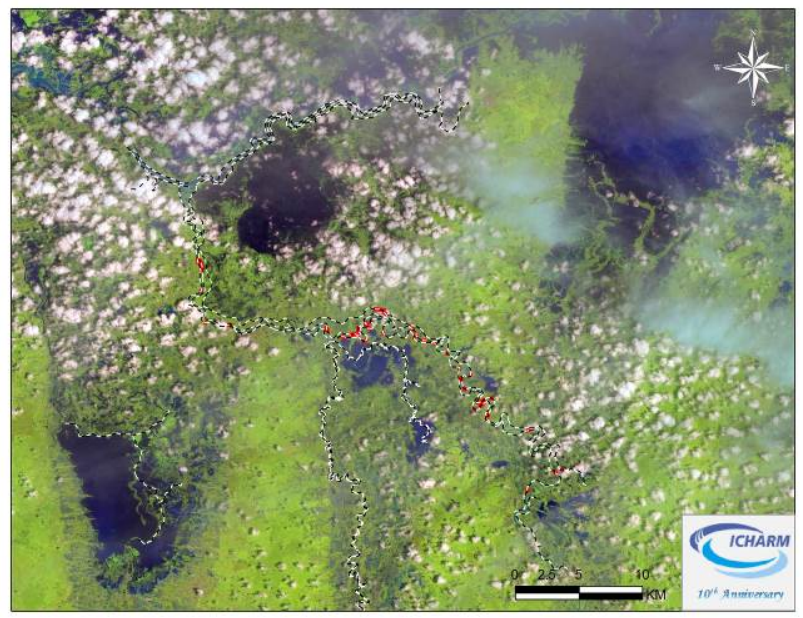

Figure 8. Damage data (red line) in combination with Landsat 8 RGB composite image acquired on 22 Aug. 2017

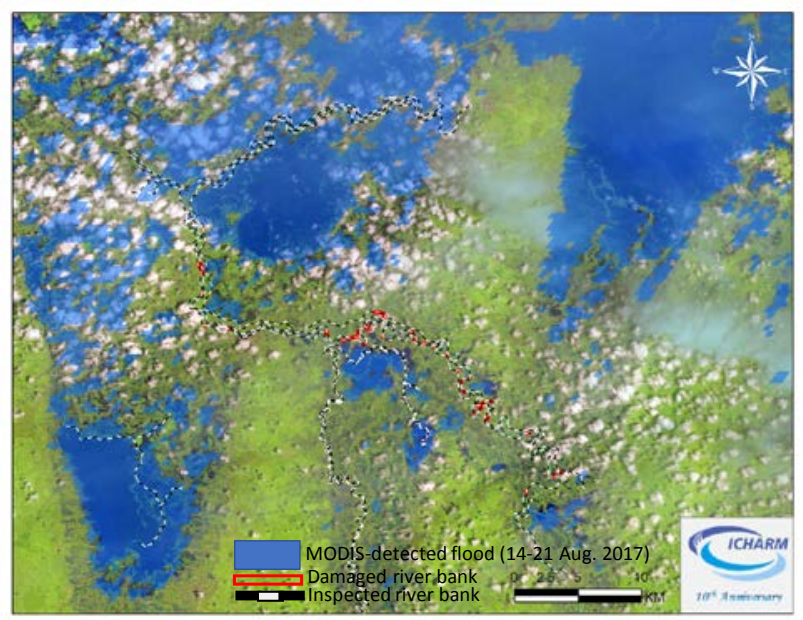

Figure 9. Damage data (red line) in combination with MODISdetected flood (14-21 Aug. 2017) on the Landsat 8 RGB image

\section{CONCLUSION AND REMARKS}

Ideas and lessons learned from the pilot study implementation are listed below:

(1) According to the results of the inventory survey with GIS mapping, most embankment failures along the Manu River concentrate in the outer bends of the river.

(2) GIS-based maps with MODIS-detected flood analysis can show the conditions of embankment failure and help understand the relationship between the critical points and inundation areas.

(3) GiFM will be able to improve the prototype of a flood hazard map and contribute to community-based disaster risk reduction and sustainable water related infrastructure management as non-structural measure. In particular, it will be very useful for undetected flood areas in developing countries like Bangladesh.

\section{ACKNOWLEDGEMENTS}

This pilot study is fully supported by the Grant Aid of the Project for Capacity Development of Management for 
Sustainable Water Related Infrastructure from the technical assistance project given by the Government of Japan. We sincerely thank honourable Mr. Mahfuzur Rahman, Director General of Bangladesh Water Development Board, for his great cooperation, valuable suggestions and constant encouragement.

\section{REFERENCES}

Bangladesh Water Development Board., 2016. BWDB Annual Report 2015/2016, Bangladesh Water Development Board.

Kwak, Y.J.; Arifuzzanman, B.; Iwami, Y., 2015a. Prompt Proxy Mapping of Flood Damaged Rice Fields using MODIS-derived Indices. Remote Sens. 2015, 7, 15969-15988.

Kwak, Y.; Park, J.; Fukami, K., 2014a. Near real-time flood volume estimating from MODIS time-series imagery in the Indus River basin. IEEE J. Sel. Top. Appl. Earth Obs. Remote Sens. 2014, 7, 578-586.

Kwak, Y. 2017a. Nationwide Flood Monitoring for Disaster Risk Reduction Using Multiple Satellite Data, ISPRS Int. J. Geo-Inf. 6, pp. 203-215 https://doi:10.3390/ijgi6070203

United Nations., 2015. Sustainable Development Goals 2030, URL http://www.un.org/sustainabledevelopment/sustainabledevelopment-goals/

United Nations University., 2014. World Risk report 2014, United Nations University

https://ehs.unu.edu/news/news/world-risk-report-2014.html

QGIS Development Team, 2008. QGIS Geographic Information System. Open Source Geospatial Foundation. URL http://qgis.osgeo.org

World Bank, 2008. Water Management Improvement Project. URL http://projects.worldbank.org/P040712/watermanagement-improvement-project?lang=en 